\title{
A PUBLIC RELATIONS SUPPORTED APPROACH TO EMOTION MANAGEMENT PROCESS IN HOSPITALS
}

\section{Simge ÜNLÜ KURT ${ }^{1}$}

\begin{abstract}
The healthcare sector includes a working area where emotions are experienced at a high rate. The patient and his / her relatives may not be familiar with the situation, and the risks associated with it may be quite high. There may be a possibility that the patient may die or fall into a situation that is too bad to be treated, other doctors and staff consulted may raise suspicions about the current treatment and other patients' current situation may influence mood in a positive or negative way. In this process, the emotion management process is of great importance and public relations practices are considered to be a guiding attribute in the healthcare sector. In this context, first of all, information about the process of emotion management and its practice in the healthcare sector will be conveyed, approaches to the subject in terms of public relations and the finding from the semi-structured interviews will be presented. These semi-structured interviews made with the patients and their relatives in understanding emotional conditions in hospitals. The works of Lewis (2005) and Smith and Kleinman (1989) were used in order to prepare the interview forms and to the questions. Findings of interviews show that patients and their relatives mostly affecting by approaches of the personal and the events which they witnessed and also according to participants, in state hospitals there is a lack of concern about giving good experiences to patients.
\end{abstract}

Keywords: Emotion Management, Healthcare Sector, Hospitals, Public Relations

\section{HASTANELERDE DUYGU YÖNETIMI SÜRECİNE HALKLA ILISSKILER DESTEKLI BÍR YAKLAŞIM}

$\ddot{O z z}$

Sağlık sektörü duyguların yüksek oranda olduğu bir çalışma alanını içermektedir. Hasta ve hasta yakınlar içerisinde bulundukları duruma aşina olmayabilmekte ve bunun beraberinde riskler bir hayli yüksek olabilmektedir. Hastanın ölüm veya tedavi edilemeyecek kadar kötü durumlara düşme ihtimali bulunabilmekte, danışılan diğer doktor ve personeller mevcut tedaviye ilişkin şüpheler uyandirabilmekte ve de diğer hastalarn mevcut durumu duygu durumunu olumlu ya da olumsuz doğrultuda etkileyebilmektedir. Bu süreç dahilinde duygu yönetimi süreci büyük bir önem arz etmekte ve halkla ilişkiler pratiklerinin sağlık sektöründe duygu yönetimi hususunda yol gösterici bir niteliği olduğu değerlendirilmesinde bulunulmaktadır. Çalışmada bu bağlamda öncelikle duygu yönetimi ve sağlık sektöründe uygulanma süreçleri hakkında bilgiler ardından halkla ilişkiler açısından konu hakkındaki yaklaşımlar aktarlacaktır. Son olarak ise hasta ve hasta yakınları ile yapılan yartyapılandırılmış görüşmelerden elde edilen bulgular sunulacaktır. Yarı-yapılandırılmış görüşmeler hastanelerdeki duygu durumlarının anlaşılabilmesi adına hasta ve hasta yakınlar ile yapılmıştır. Görüşmelerde kullanılan formlar ve soruların hazırlanılmasında Lewis (2005), Smith ve Kleinman'ın (1989) çalışmalarından yararlanılmıştır. Görüşmeler sonucunda hasta ve hasta yakınlarının büyük oranda personelin kendilerine yaklaşımı ve şahit oldukları olaylardan etkilendiklerini ortaya çıkarmıştır. Ayrıca ulaşılan bir başka sonuç ise devlet hastanelerinin hastalarına iyi bir tecrübe yaşatmak konusunda gerekli kaygılara sahip olmadiğını göstermektedir.

Anahtar Kelimeler: Duygu Yönetimi, Sağlık Sektörü, Hastaneler, Halkla İlişkiler

${ }^{1}$ Arş.Gör.Dr., Sakarya Üniversitesi, İletişim Fakültesi, Halkla İlişkiler ve Reklamcllı Bölümü, simgeunlu@sakarya.edu.tr, orcid.org/0000-0002-0137-4210 


\section{Introduction}

The concept of emotion management (EM) defines different strategies that an individual can use to control his or her particular emotions. Five emotional processes, each of which covers different regulatory strategies, are summarized as follows.

- State selection: To choose a state where the preferred emotions will be reflected and an active role will be taken effect

- State regulation: To regulate the state on in order to change the emotional

- Attention diversion: To divert the attention to a specific situation

- Cognitive change: post-state: To change in order to change the emotional importance of the assessments related to the state (Gross, 1998 225; Gross and Thompson, 2007: 16-17).

As mentioned above, each of these strategies covers different processes and can therefore be used simultaneously. However, there is no restriction on this, and it can be seen that these strategies can be implemented as a whole. Accordingly, the process can be realized as shown below.

Figure 1: Process of Emotion Management

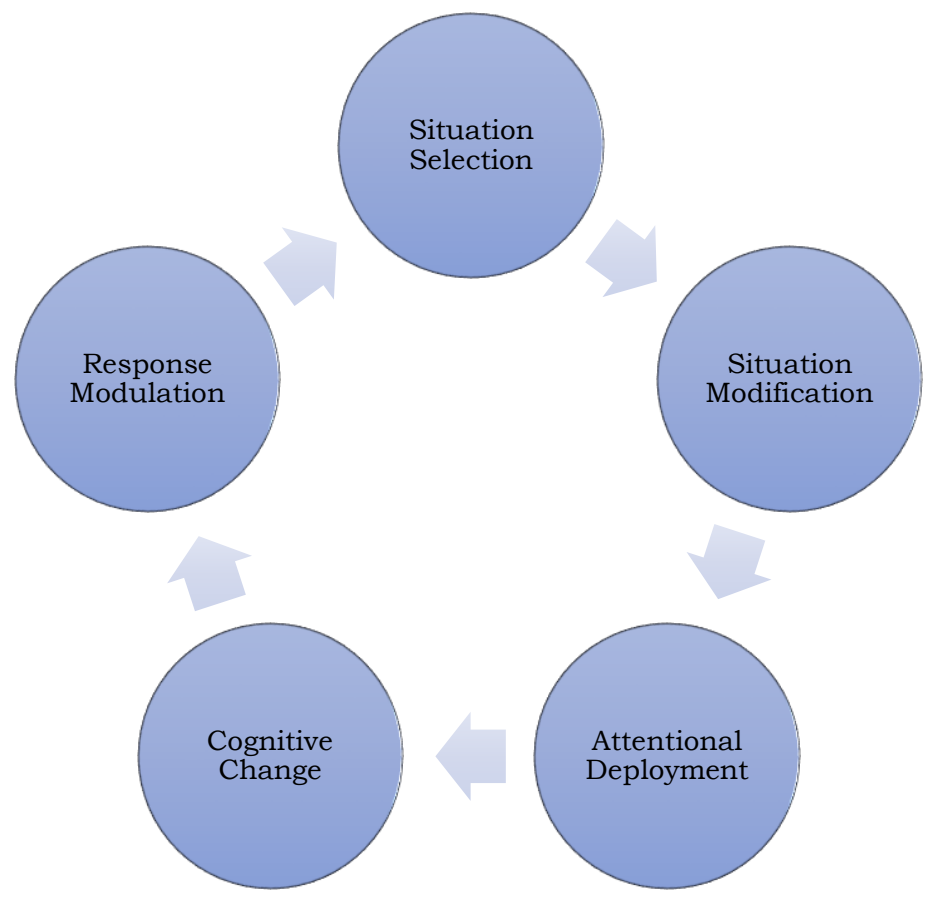

Source: Gross, 1998: 225; Gross and Thompson, 2007:16-17.

First of all, the reason why emotion management strategies are presented in a circular schema should be considered as a result of a public relations linked approach. Accordingly, public relations flow, which hosts research, planning, implementation and assessment processes, leads to a conceptual flow that will be created for the emotional adjustment strategies in the literature. Accordingly, determining the emotional state, drawing a road map for the arrangement of emotions, taking action for the realization of the change and assessing the final situation are associated with the public relations process. In the same way, the reason for creating a cyclical process is that a critical analysis process is required to provide future-oriented data and to create viable pro-active emotion 
management strategies in light of the assessments made after the implementation as in public relations.

\section{Emotion Management}

The successful emotional adjustment activities implemented through the implementation of strategies show that the performance and happiness of the employees in the healthcare sector are effective in increasing the time spent listening to the patients, decreasing the exhaustion and increasing the emotional satisfaction (Zammuner et al., 2003: 43-47). Successful emotional adjustment also points to an increase in the empathy level of health care personnel. In cases where the current state of the patient causes negative emotions, it is difficult for the employee to express empathy with the patient because there is nothing he can do to correct it or turn it into positive (Decety et al., 2010: 1676-1679; Gleichgerrcht and Decety, 2014: 2). This situation is seen as a preventive factor in the treatment process as will be stated in the following parts of the study.

When we get to the root of the subject, understanding the emotions of patients and managing them is an important field for the employees. Emotions in the field of healthcare directly and indirectly affect patients, relatives and health care personnel. Patients and relatives develop and maintain different emotions that may have profound effects throughout the treatment period. The treatment process can include chronic diseases along with outpatient treatment processes consisting of mild diseases, and can express the time interval when the intensity of emotions faced with vital danger is much higher. Therefore, the healthcare sector is considered to be one of the most important fields of emotion management. Patients can be usually weak and may have lost control of their bodies, mental status and perceptions of the services they receive. These situations can lead to a negative perception of the healthcare sector's patient services, such as resistance to treatment, and even a complete rejection of treatment. When considered from an individual point of view, the negative urges of the illness created in the emotional world of the individual can lead to loneliness and depression in the patient and even prevent the immune defence process (Faulkner, 2001: 943-946).

In the treatment process, not only the patients and their relatives, but especially the sector employees who intervene first to the patients can undergo emotional difficulties. This situation can cause emotional disturbances and stress in employees, and these indicators, as a result, may lead to the wrong treatment of patients to go through the sequence of errors (Kahneman and Deaton, 2010: 16489). The researchers, who carried out studies on the subject, conducted studies on the benefits of keeping the emotional state of patients, patient relatives and health care workers under control during the treatment process (Lee et al., 2013: 28).

One of the most important steps in an approach to emotion management is to remember that it is a process from the application of the patient and his / her relatives to the health care institution to the completion of the treatment taken. Therefore, in this process, instead of an emotion and its extensions, a "whole of emotions", which change over time and change into different branches with each interaction entered with patient/patient relatives and health care personnel can be mentioned. For example, after triggering conditions such as chronic disease diagnosis, the reactions of patients and relatives cause a series of emotional indicators that can influence health care personnel and that these indicators show themselves during treatment. The important point here is that the reactions are 
not within the daily mental processes but rather through the reactions that emotions are driven by. As the duration of treatment is prolonged, the patient and his / her relatives' increased levels of stress, as well as different triggers such as financial difficulties, family problems and lack of support that health care personnel may experience, may show themselves in the transfer of emotions (McColl-Kennedy et al., 2017: 1-2).

\section{The Nature of Patient Emotions}

The healthcare sector has many actors and a complex process in which the patient / client plays an active role throughout the process. Depending on the patient or situation, the customer tends to contact not only the healthcare institution in the centre, but also other hospitals, healthcare companies or product providers in the sector. For example, in psychological treatment processes, with support from other therapists, the family, friends or other patients are constantly communicating and a complex network system in which the perceptions can be shaped depending on the central health institution is formed (McColl-Kennedy et al., 2017: 2).

Figure 2: The Nature of Patient Emotions

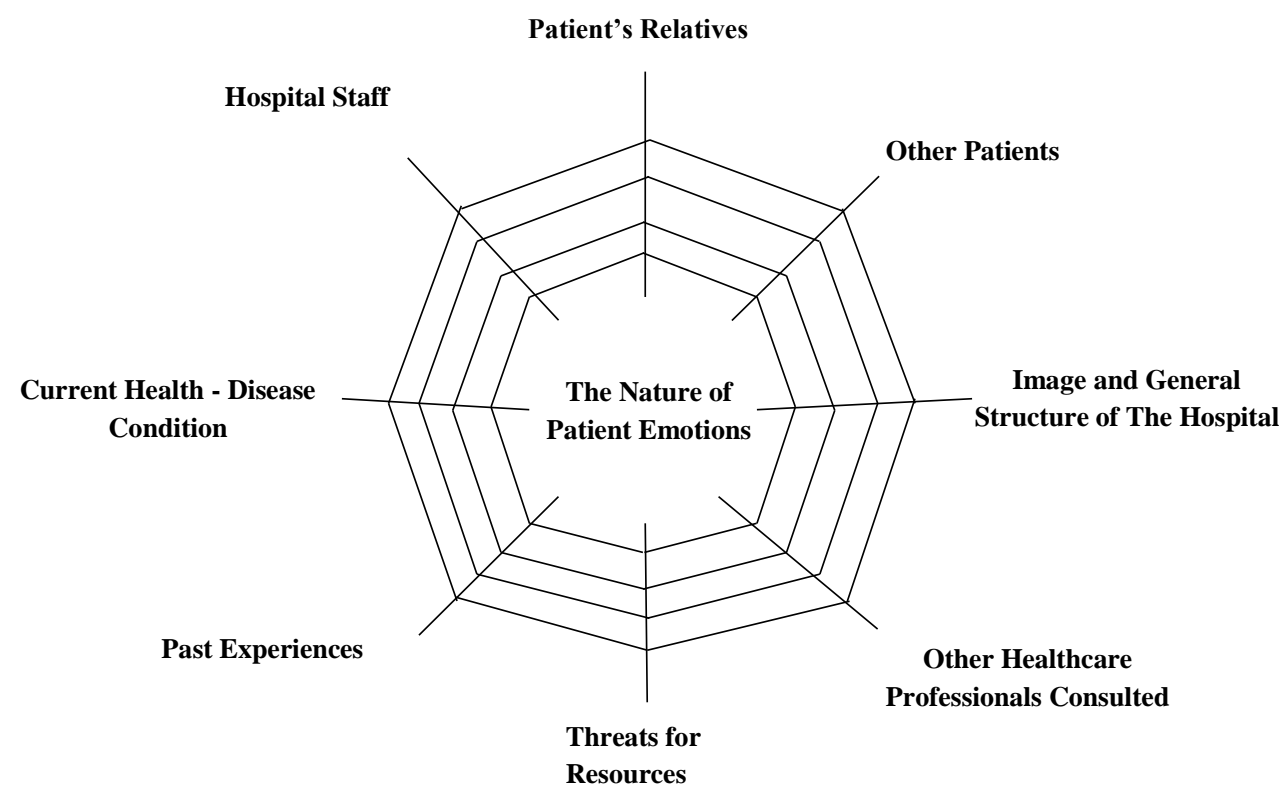

The healthcare sector includes a working area where emotions are experienced at a high rate; the patient and his / her relatives may not be familiar with the situation, and the risks associated with it may be quite high. There may be a possibility that the patient may die or fall into a situation that is too bad to be treated, other doctors and staff consulted may raise suspicions about the current treatment and other patients may influence their current situation in a positive or negative way. 


\section{Emotion Management Process and Public Relations Approach in Healthcare Sector}

Healthcare services can be transferred to various areas and institutions according to the needs identified and thus may allow interventions to be made according to emergencies or planned crisis situations. One of the most important missions of the healthcare sector is not to harm patients and their relatives in such a way as to cause more emotional breakdown on the current situation. Such that, physical and psychological health is directly related to one's emotional state. In this context, it is of great importance that all sector employees, especially health personnel who are in direct contact with the patients and their relatives, should carefully and consciously control the emotions of the patients and, if necessary, influence (Lee et al, 2013: 29).

Emotions can be caused by the behaviours of others, a change in the existing situation, or external effects caused by a new stimulus, or by the effects of internal stimuli, such as thoughts or memories. In general, emotional processes are known to last a short period of time and over time lose its effect. It is one of the important factors determining the success of the treatment process, including which events and stimulants affect the emotional state of the employees and the consistent and valid predictions about the effects of the affected emotional state on the physical and mental structure of the individual. 4 different indicators that can guide these predictions can be listed as follows (Baker et al., 2005: 134-135):

- Objects: Drugs or medical equipment used during treatment may play a role as triggers of emotional state.

- Conditions: The patient's health status, current complaint and treatment facilities are other emotional triggers.

- Personal and psychological resources: Indicators such as self-esteem, positive attitude and sense of justice are emotional triggers.

- Energy: Personal competence and resources such as time and money.

Any threat situation related to the 4 indicators listed above can lead an emotion that develops and grows in a sudden or process. For example, in a hospital, the emotion that a patient is at risk of health due to the lack of staff intervention or the inability of the patient and his / her relatives to provide the necessary medication can lead to a negative state of emotions that can lead to anxiety, stress and even violence.

To give an example of the emotions entered into the long-term process, the constant increase in the costs of the patient in prolonged treatment processes may cause him to feel that his personal resources are at risk and in this case, it can lead to negative emotions, which can extend up to resistance to treatment and even completely reject treatment.

Emotion regulation refers to the shaping of emotional reactions to achieve goals through observation, assessment and arrangement within the context of internal and external effects (Thompson, 1994: 27). Emotion regulation process involves conscious or unconscious interventions that can be used in the active process of emotional reactions (Varzeletti et al., 2016: 2).

The key point of the concept is that it is composed of both the person's own emotions and the process of regulation someone else's emotions (Gross, 1999). The process of arranging emotions is based on what kinds of emotions the patient and his / her relatives have, how long and how long he / she will have them, and how he / she will express them. In this process, two strategies are used effectively. 
These are shown as cognitive re-evaluation and impressive suppression. Cognitive re-evaluation aims to change the emotional effect by consciously altering the structures that make up the emotion and the goal is to reduce negative emotions and/or transform negative emotions into positive. Impressive suppression, on the other hand, attempts to control emotions taking into account the circumstances. This strategy, unlike cognitive re-evaluation, is not trying to change emotions, but to suppress their forms of expression (McColl-Kennedy et al., 2017). Another point that needs to be considered is the issue of emotional contamination. This concept refers to the person's ability to copy facial expressions, voice tones, posture and even movements in the environment, both automatically and simultaneously, just like the risk of a disease infecting other patients, refers to the danger of infecting and affecting other patients and their relatives with the emotion in the environment.

Figure 3: A Model Related To The Healthcare Sector

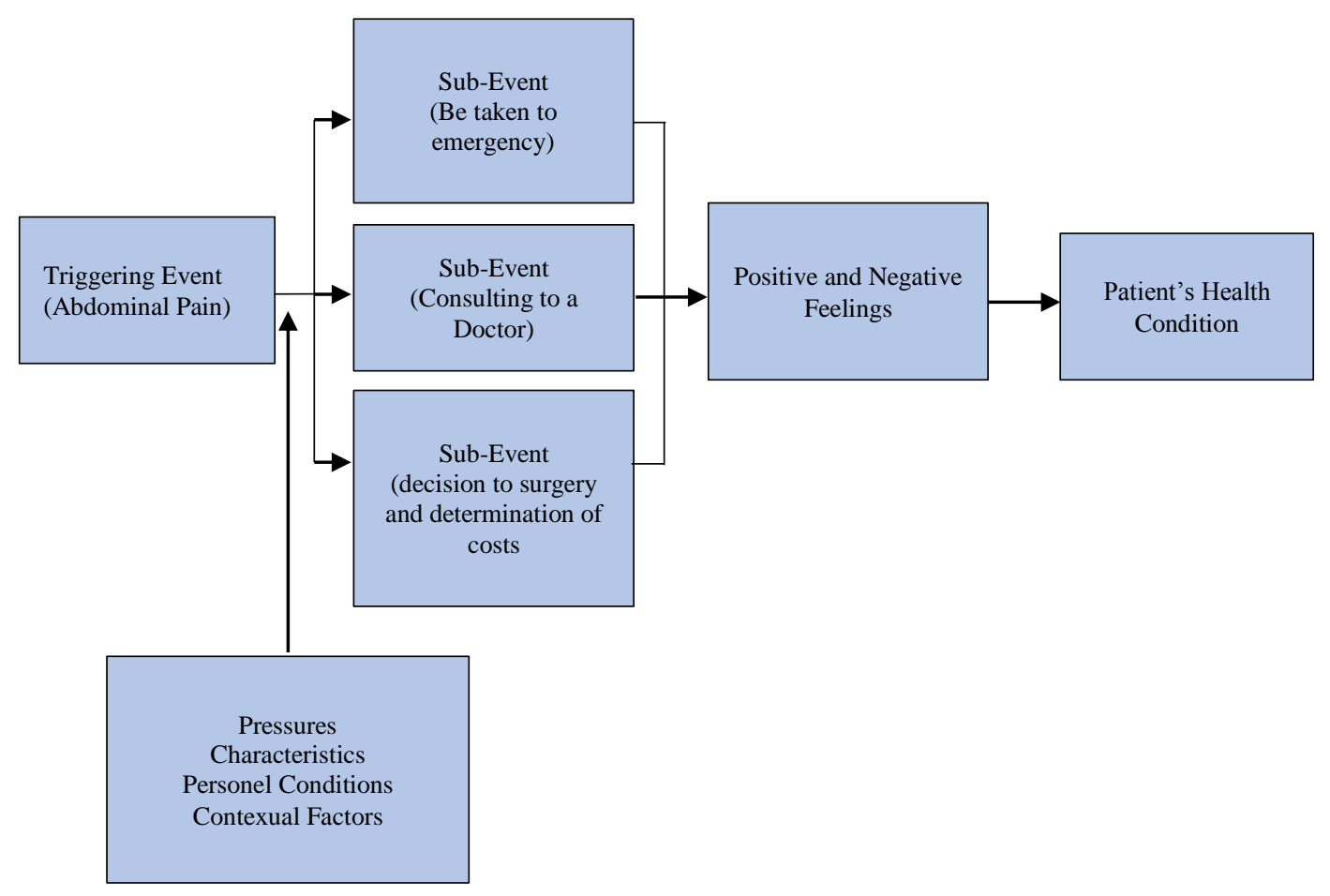

Source: McColl-Kennedy et.al, 2017: 7

In terms of public relations, the concept of rational management was generally prevalent in institutions until the 1980's when emotion management was approached again and it was argued that making sensible decisions is the only secret of effective management (Charles and Kim, 1988: 86). The researchers who conduct research on organizational behaviour saw the thoughts as values that could increase the efficiency of the institution, as well as the ability to solve problems and the emotions that prevented them from making rational decisions, and regarded the negative as the "troublesome" that should be ignored or dealt with (Grunig, 2013: 11). However, over time, this view has changed and it has begun to be accepted that emotions are the main motivators of making rational decisions and that the pre-acceptance that people will have difficulty assessing alternatives without involving their emotions. 
In particular, Finemann has pioneered that emotions can be effectively applied in different areas such as decision making, persuasion, marketing and agreement, as well as in the field of public relations, to be considered as a holistic management practice, including those studies involving only negative emotions such as violence, mobbing and sex discrimination. The concept of 'emotional intelligence', which Goleman comes up with as an ability to understand someone else's emotions, to manage these emotions, to motivate oneself and to improve established relationships does not ignore the fact that they are effective (Goleman, 1996: 43-44; Finemann, 2004: 721) although Finemann criticizes the fact that emotions become a marketable product within the organization.

In Goffman's book, "Presentation of the Self in Everyday Life" (1949), control of one's own emotions and emotions of others has been seen as a fundamental skill for the survival or destruction of a company in a business or service sector. Especially with the increase of service companies operating in the sector, the approach to emotions has changed and has started to attract more attention.

This approach, conceptualizing as emotional labour, refers to the reflection of emotions in an observable way to the external appearance, the management of this process, and the use of profit as a means of change (Fineman, 1997: 17; Hochschild, 1983: 7). The concept refers to the studies of the organization of "visible" emotions about the roles undertaken in accordance with the organization's objectives (Brotheridge and Lee, 2003: 365). The process of emotional labour refers to the careful reflection of non-verbal communication elements, such as verbal communication and even facial expressions, voice tone, gestures and mimics. When thought is combined with emotion management, emotional labour manifests itself in the process of transforming emotions into behaviour rather than emotions in the application phase.

In the healthcare sector, emotion management is considered a much more important process for caregivers and nurses than for other staff. In particular, the process of suppression of emotions increasing with the length of some treatments and the uncertainty of the process means that both the patient and the health care personnel will struggle with various challenges during the treatment process as mentioned in the previous paragraphs, therefore, the control of emotions is seen as an inevitable strategy from the perspective of health personnel (Bolton, 2001: 85; Iş1k, 2011: 40). In addition, especially nurses can experience intense negative emotions such as disgust, irritability and anger. These emotions reflected naturally in behaviours during the treatment process of the patient cause negative effects.

One of the most important problems encountered in emotion management, as mentioned above, is the perception that the emotion management process should be carried out by "women" in the health care institution. However, when the situation is considered in terms of men in the sector, it is not an approach where emotions are taken care of, but rather a technique of communication and transfer of emotions, especially in the specialty of doctors, are made up of technical procedures and interventions. In such an approach, it is quite difficult to understand emotions and to adopt an appropriate approach to the emotion management process. Therefore, emotional processes are almost entirely on nurses. In this respect, the doctors' defence in their own respects contains a share of rights as follows: "Emotions can prevent the process of diagnosis; therefore, you have to try to remain objective. This is a better way to give the necessary medication and leave the nurse to deal with emotions" (McCreight, 2005: 441; Smith and Gray, 2000: 94). 


\section{Research}

\subsection{Method}

In this qualitative research, semi-structured interviews were made with the patients and their relatives to understand emotional conditions in hospitals. As a data collection tool, interviews included questions regarding to: relations with the personnel, values of patients and their relatives' and the factors that could lead to changes in emotional state in general. The works of Lewis (2005: 569-574) and Smith and Kleinman (1989: 57-60) were used in order to prepare the interview forms and to the questions. All interviews lasted about 15 minutes and expanding questions were also addressed along with main questions. During the interviews, recordings were taken and in reporting process transcription of these recordings were completed after several verifications.

Information on participants is given in the table below.

Table 1: Participants

\begin{tabular}{|l|l|c|}
\hline Type / Code of Participant & Gender & Age \\
\hline Patient 1 / P1 & Female & 57 \\
\hline Patient 2 / P2 & Female & 32 \\
\hline Patient 3 / P3 & Female & 35 \\
\hline Patient 4 / P4 & Male & 39 \\
\hline Patient 5 / P5 & Male & 22 \\
\hline Patient Relative 1 / PR1 & Male & 42 \\
\hline Patient Relative 2 / PR2 & Male & 26 \\
\hline Patient Relative 3 / PR3 & Male & 44 \\
\hline Patient Relative 4 / PR4 & Female & 25 \\
\hline Patient Relative 5 / PR5 & Female & 37 \\
\hline
\end{tabular}

Participants were selected for research from 3 states and 3 private hospitals in İstanbul, Sakarya and Kocaeli provinces among random patients and relatives waiting for the treatment. Interviews were made within 6 days in these hospitals -which were selected to be close to each other for accessibility. During the interviews, the researcher reminded the participants of the voice record and gave the necessary information regarding to aim and scopes of the research. Also, no personal information was requested and participants were informed about the fact that they could end the interview whenever they wanted.

The interview questions are as follows:

Table 2. Interview Questions

\begin{tabular}{|c|c|}
\hline Interview Questions & Expanding Questions \\
\hline $\begin{array}{l}\text { What are the factors that affect your mood } \\
\text { positively or negatively in state hospitals and } \\
\text { private hospitals?" }\end{array}$ & \multirow{3}{*}{$\begin{array}{l}\text { Why are you in hospital? } \\
\text { Have you / your relatives ever been to a } \\
\text { private hospital / state hospital for this } \\
\text { complaint? } \\
\text { Could you give examples of situations } \\
\text { you faced? }\end{array}$} \\
\hline $\begin{array}{l}\text { As far as you can see, how health care personnel } \\
\text { respond to sudden emotional reactions and } \\
\text { what direction do they follow?" }\end{array}$ & \\
\hline $\begin{array}{l}\text { Do you think there are emotional problems faced } \\
\text { by health care personnel? If you think so, do you } \\
\text { think that these problems are reflected in } \\
\text { patients? }\end{array}$ & \\
\hline
\end{tabular}


The responses to the questions from the interview reflect the subjective judgments and values of the participants and contain a small number of sample group residing in a specific region within the selected provinces. So, it is not possible to generalize participants' views to all patients or their relatives in Turkey. However, the findings are important because of the certain predictions regarding the emotional state and the guiding for future studies. In addition, the inclusion of the opinions of health professionals with different job descriptions in the studies that serve similar purposes will play a role in the further development and enrichment of the findings of this study.

The findings of the interviews enable the direct witnesses to listen to current issues from scratch, while also ensuring data collection for the research process so that a public-focused approach can be identified. In this way, the infrastructure which is required to configure the model has been obtained.

\subsection{Interviews}

The answer of P1, who first of all approached from the perspective of private hospitals to the question of "What are the factors that affect your mood positively or negatively in state hospitals and private hospitals?" is as follows: "The common goals of the healthcare sector (...) is to create a happy customer portfolio. The futility of advertisements, lie-filled unreliability glut is not in a position to be discarded. For this reason, the Happy Customer potential of the brand is always in the forefront in terms of identity and confidence formation. I saw this in private hospitals; the administration chooses the staff of the hospital very well. You can always see that positive energy on their faces. Patients are also going to the hospitals in a conditioned manner. Patients go to private hospitals with the assurance that they will receive every penny they spend on health. There are a lot of people who keep the path of the private hospital after having a trauma in the state hospital." P1 answered the question within the frame of state hospitals as follows: "The situation in state hospitals is somewhat more dependent on locality. Istanbul is a very crowded city. In this crowd, "the limitations of service are in fact responding to this situation, that is, it becomes a more monotonic, irritable, irrelevant mood."

There are two distinctive issues in $\mathrm{P} 1$ 's response to private hospitals. The first of these is that private hospitals act like corporate companies and try to provide quality services by treating patients as customers. To be seen as a customer in a hospital is not irritating to P1's interpretation if the quality of service received is high. The second issue is that those who are not satisfied with the service offered in the state hospital or those who see private hospitals as more reliable may prefer private hospitals. Accordingly, previous negative experiences can affect hospital selection, as well as result of the fact that private hospitals can create a more reliable image and emotion.

PR5 on the other hand, answered the question as follows:

... the most negative thing that affects my mood is a patient's loss of close relatives and his / her screaming; on the positive side, the doctor's kindness gives me confidence that he's interested in me. The negative effect of the state hospitals is that the queue number given to me is being extorted by others and unfortunately, doctors do not care about this.

In response to this question, the answers of PR2 and P3, who did not comment on the separation of state hospital - private hospital, are respectively as follows; 
"I feel so sad when I see people suffering and hear their negative stories. However, it is happy to see that people are struggling against diseases." (PR2) and "the healing of patients in health care institutions affects my mood positively. But those who desperately wait to die or leave the hospital with their lifeless bodies have a negative impact on me. (P3)"

These two expressions show two different ends of change in the emotional state in hospitals.

The second question directed to the participants is: "as far as you can see, how do health care personnel respond to sudden emotional reactions and what direction do they follow?"

P5 commented on this issue as follows:

Although this situation is not very important since the private sector is generally staffed with experienced staff, the atmosphere of trainee massacres in state hospitals and patients continue their lives with terrible experiences. The interns who have difficulty in putting theoretical knowledge they learned at school into real life can do bad things to patients. For example, it happened to someone I knew. The intern nurse tore a vein. A wrong operation can cause very bad results.

While the view of PR5 about the process is that "Professional health personnel can easily control themselves in a sudden change in emotions. But those who do not develop their professionalism may get scared and excited and become unable to do their work, and they get away by crying and even fainting.", PR3 commented as follows; "Most of the time, health care personnel may react with anger to sudden emotional reactions. I would think that such a response is natural, if we were to empathize and think that the other employee was taking care of all the people there."

While PR4 describes the normal functioning of the process as "health care personnel react calmly to sudden, emotional reactions to prevent the patient from feeling panicked", P2 compares the private hospitals and state hospitals and transfers the process as follows: "I see the psychological state of the personnel reflected to the patients more in the state hospitals. The staff acts a little arbitrarily with the comfort of their authority. However, in the private hospitals, probably due to their concerns, the focus is on the patient. So, it's not psychological."

After the question was asked, PR2 gave an example of an incident he experienced while giving his views on the subject:

Health care personnel are unfortunately very indifferent in state hospitals. Especially in the emergency rooms. I came to the E. R. with my wife last night because of stomach discomfort to get a serum. They told us that there was no stretcher available. When the man behind us responded by shouting at this situation, the attitude of the nurse and the doctor changed, and they started to use a harder tone.

The last question directed to the participants is as follows: "Do you think there are emotional problems faced by health care personnel? If you think so, do you think that these problems are reflected in patients?"

While PR4 expresses his views on this subject as;

In private hospitals, there is a fear of being fired at any time for they are working on contracts. In addition, patients who go to private 
hospitals become more conscious and complain about every problem they face to human resources. This leads the employees to be more cautious.", P4 stated that "Our people are a bit more understanding in state hospitals; however, not everyone is the same. We're not paying any fees here anyway. They're so interested in us, they think we need to be a little more understanding of them.

In parallel with the last sentence of P4, P2 expressed "At the State Hospital, we see that some patients and relatives have been subjected to bullying, and even the news of the doctors who were beaten in the media is coming out. Of course, this is reflected in the patient, the health care personnel want to do their job and leave."

With a different approach, PR3 interpreted the mood of the health care personnel as follows: "I don't think health care personnel have emotional problems because they do the same thing all the time and are subject to the same events."

PR1 explained an incident about the subject he experienced as follows: "I recently saw the girl in the consultation being scolded by the doctor's secretary. She was upset because the secretary let a patient in, before the other left the room. This was reflected in her voice and work. She gave the wrong change."

\section{Conclusion}

Emotion management in the healthcare sector is of great importance both within the framework of patient and patient relatives and within the framework of healthcare sector employees. In this study, within this context, first of all, emotion management, the nature of patient and patient relatives, and the problems that health care workers experience were presented with their causes and possible consequences, then, the information presented in the literature from the framework of the healthcare sector for emotion management was included. After the literature part, with the help of the questions prepared, the data collection process was completed by interviewing the patients and their relatives.

Throughout the parts that are connected with public relations, the foundations of modern management practices and two-way communication understanding are based on the principles of modern public relations, humanoriented working principles in the healthcare sector, how and at which levels the emotion management processes can be used are presented within the context of approaches in the literature, conducted interviews and the similarities between emotion management processes and public relations practices.

Findings of interviews show that patients and their relatives are mostly affected by approaches of the personnel and the events which they witness. This finding is seen as important because the comprasion -according to interviewsbetween state and private hospitals shows that the "customer" oriented approach of the private hospitals is making it possible for patients to have a better experience. But their "corporation-like" business system may cause negative effects on their personnel as well as the positive performance system. On the other hand, according to participants, in state hospitals there is a lack of concern about giving good experiences to patients and also there are only a few cases where the illness is treated well so this causes patients to prefer private hospitals even they know they will pay more. 


\section{References}

Baker, S. M., Gentry, J. W. and Rittenburg, T. L. (2005). Building Understanding Of The Domain Of Consumer Vulnerability. Journal of Macromarketing, 25(2), 128-139.

Bolton, S. (2001). Changing Faces: Nurses As Emotional Jugglers. Sociology of Health \& Mlness, 23(1), 85-100.

Brotheridge, C. M., and Lee, R. T. (2003). Development And Validation Of The Emotional Labour Scale. Journal of Occupational and Organizational Psychology, 76(3), 365-379.

Charles, M. T., and Kim, J. C. K. (Eds.). (1988). Crisis Management: A Casebook. CC Thomas.

Decety, J., Yang, C. Y., and Cheng, Y. (2010). Physicians Down-Regulate Their Pain Empathy Response: An Event-Related Brain Potential Study. Neuroimage, 50(4), 1676-1682.

Faulkner, M. (2001). Empowerment, Disempowerment And The Care Of Older People. Nursing Older People, 13(5), 18-20.

Fineman, S. (2004) Getting The Measure Of Emotion And The Cautionary Tale Of Emotional Intelligence. Human Relations 57, 719-740.

Fineman, S. (1997). Emotion And Management Learning. Management Learning, 28(1), 13-25.

Gleichgerrcht, E. and Decety, J. (2014). The Relationship Between Different Facets Of Empathy, Pain Perception And Compassion Fatigue Among Physicians. Frontiers In Behavioral Neuroscience, 8, 243.

Goffman, E. (1949). The Presentation Of Self In Everyday Life. American Journal of Sociology, 55, 6-7.

Goleman, D. (1996). Emotional Intelligence. Why It Can Matter More than IQ. Learning, 24(6), 49-50.

Gross J. J. and Thompson R. A. (2007). Emotion Regulation: Conceptual Foundations. In:Gross James J, Editor. Handbook Of Emotion Regulation. New York: Guilford Press; 2007. p. 3-24.

Gross, J. J. (1998). Antecedent-And Response-Focused Emotion Regulation: Divergent Consequences For Experience, Expression, And Physiology. Journal Of Personality And Social Psychology, 74(1), 224.

Gross, J. J. (1999). Emotion Regulation: Past, Present, Future. Cognition \& Emotion, 13(5), 551-573.

Grunig, J. E. (2013). Excellence In Public Relations And Communication Management. UK:Routledge.

Hochschild, A. R. (1983). The Managed Heart: Commercialization Of Human Feelings. Berkeley, CA: University of California Press.

Issık, M. (2011). Hastanelerde Halkla İişkiler, Konya: Eğitim Kitapevi.

Kahneman, D. and Deaton, A. (2010). High Income Improves Evaluation Of Life But Not Emotional Well-Being. Proceedings of The National Academy Of Sciences, 107(38), 16489-16493. 
Lee, H., Vlaev, I., King, D., Mayer, E., Darzi, A. and Dolan, P. (2013). Subjective Well-Being And The Measurement Of Quality In Healthcare. Social Science $\&$ Medicine, 99, 27-34.

Lewis, P. (2005). Suppression Or Expression: An Exploration Of Emotion Management In A Special Care Baby Unit. Work, Employment And Society, 19(3), 565-581.

McColl-Kennedy, J. R., Danaher, T. S., Gallan, A. S., Orsingher, C., Lervik-Olsen, L. and Verma, R. (2017). How Do You Feel Today? Managing Patient Emotions During Health Care Experiences To Enhance Well-Being. Journal Of Business Research, 79, 247-259.

Mccreight, B. S. (2005). Perinatal Grief And Emotional Labour: A Study Of Nurses' Experiences In Gynae Wards. International Journal of Nursing Studies, 42(4), 439-448.

Smith III, A. C. and Kleinman, S. (1989). Managing Emotions In Medical School: Students' Contacts With The Living And The Dead. Social Psychology Quarterly, 56-69.

Smith, P. and Gray, B. (2000). The Emotional Labour of Nursing: How Student and Qualified Nurses Learn to Care; a Report on Nurse Education, Nursing Practice and Emotional Labour in the Contemporary NHS. London, England: South Bank University, Faculty of Health.

Thompson, R. A. (1994). Emotional Regulation: A Theme In Search Of Definition. Monographs Of The Society For Research In Child Development, 59(2/3), 3303.

Verzeletti, C., Zammuner, V. L., Galli, C. and Agnoli, S. (2016). Emotion Regulation Strategies And Psychosocial Well-Being In Adolescence. Cogent Psychology, 3(1), 1199294.

Zammuner, V. L., Lotto, L. and Galli, C. (2003). Regulation Of Emotions In The Helping Professions: Nature, Antecedents And Consequences. Australian EJournal For The Advancement Of Mental Health, 2(1), 43-55. 
